\title{
PEMBINAAN AKHLAK MULIA DALAM \\ BERHUBUNGAN ANTAR SESAMA MANUSIA \\ DALAM PERSPEKTIF ISLAM
}

\author{
Oleh: Marzuki \\ (PKn dan Hukum - FISE / MKU- UNY)
}

\begin{abstract}
Abstrak
Fungsi kehadiran manusia di muka bumi adalah sebagai khalifah Allah dan sebagai hamba Allah. Untuk melaksanakan kedua fungsi ini manusia harus membekali dirinya secara cukup, terutama bekal ilmu. Dengan bekal inilah manusia dapat memerankan dirinya dalam rangka membangun hubungan dengan Tuhannya (Khaliq) maupun dengan sesamanya (makhluq). Cara yang bisa ditempuh adalah melaksanakan seluruh perintah Allah dan menjauhkan diri dari seluruh larangan-Nya. Inilah konsep takwa dalam Islam yang dijabarkan dalam tiga kerangka dasar ajaran Islam, yakni aqidah, syariah, dan akhlak. Ketiga kerangka ajaran ini merupakan satu kesatuan yang saling terkait dan tidak bisa dipisahkan. Aqidah menjadi fondasi yang menjadi tumpuan berdirinya bangunan syariah dalam mencapai tujuan akhir akhlak. Karena itu, penerapan akhlak mulia dalam berhubungan antar sesama manusia tidak bisa dilepaskan dari kerangka aqidah dan syariah. Ketika orang melakukan hubungan dengan sesamanya, baik dengan dirinya sendiri, dengan keluarganya, maupun dengan masyarakatnya tetap harus didasari oleh aqidah dan syariah yang benar, sehingga tercapai akhlak mulia yang sebenarnya.
\end{abstract}

\section{Pendahuluan}

Islam yang dibawa dan diajarkan oleh Nabi Muhammad Saw. memiliki ajaran yang paling lengkap di antara agama-agama yang pernah diturunkan oleh Allah Swt. kepada umat manusia. Kelengkapan Islam ini dapat dilihat dari sumber utamanya, al-Quran, yang isinya mencakup keseluruhan isi wahyu yang pernah diturunkan kepada para Nabi. Isi al-Quran mencakup keseluruhan aspek kehidupan manusia, mulai dari masalah aqidah, syariah, dan akhlak, hingga masalah-masalah yang terkait dengan ilmu pengetahuan.

Semua umat Islam harus mendasari keislamannya dengan pengetahuan agama (Islam) yang memadai, minimal sebagai bekal untuk menjalankan fungsinya di muka bumi ini, baik sebagai 
khalifatullah (QS. al-Baqarah (2): 30) maupun sebagai 'abdullah (QS. al-Dzariyat (51): 56). Sebagai khalifah Allah, manusia harus memiliki pengetahuan dan keterampilan mengenai masalah keduniaan, sehingga dapat memfungsikannya secara maksimal. Sedang sebagai hamba Allah, manusia harus memiliki bekal ilmu agama untuk dapat mengabdikan dirinya kepada Allah dengan benar. Jika seorang Muslim dapat membekali dirinya dengan pengetahuan yang cukup, baik pengetahuan umum maupun pengetahuan agama, dan sekaligus dapat mengamalkannya dalam kehidupan sehari-hari, maka ia akan menjadi seorang Muslim yang kaffah/utuh (QS. al-Baqarah (2): 208).

Untuk memahami dan mengamalkan ajaran Islam secara mendasar, maka setiap Muslim harus memahami dan mengamalkan dasar-dasar Islam. Dasar-dasar inilah yang kemudian oleh sebagian ulama disebut kerangka dasar ajaran Islam. Kerangka dasar ajaran Islam sangat terkait erat dengan tujuan ajaran Islam. Kerangka ini meliputi tiga konsep kajian pokok, yaitu aqidah, syariah, dan akhlak. Kalau dikembalikan pada konsep dasarnya, tiga kerangka dasar Islam ini berasal dari tiga konsep dasar Islam, yaitu iman, islam, dan ihsan (HR. Muslim).

\section{Konsep Akhlak Mulia dalam Islam}

Akhlak merupakan salah satu dari tiga kerangka dasar ajaran Islam yang memiliki kedudukan yang sangat penting, di samping dua kerangka dasar lainnya. Akhlak mulia merupakan buah yang dihasilkan dari proses penerapan aqidah dan syariah. Ibarat bangunan, akhlak mulia merupakan kesempurnaan dari bangunan tersebut setelah fondasi dan bangunannya dibangun dengan baik. Tidak mungkin akhlak mulia ini akan terwujud pada diri seseorang jika ia tidak memiliki aqidah dan syariah yang baik.

Nabi Muhammad Saw. dalam salah satu sabdanya mengisyaratkan bahwa kehadirannya di muka bumi ini membawa misi pokok untuk menyempurnakan akhlak manusia yang mulia. Misi Nabi ini bukan misi yang sederhana, tetapi misi yang agung yang ternyata untuk merealisasikannya membutuhkan waktu yang cukup lama, yakni kurang lebih 23 tahun. Nabi melakukannya mulai dengan pembenahan aqidah masyarakat Arab, kurang lebih 13 tahun, lalu Nabi mengajak untuk menerapkan syariah setelah aqidahnya mantap. Dengan kedua sarana inilah (aqidah dan syariah), Nabi dapat merealisasikan akhlak mulia di kalangan umat Islam pada waktu itu.

Kata akhlak yang berasal dari bahasa Arab akhlaq (yang berarti tabiat, perangai, dan kebiasaan) banyak ditemukan dalam hadits Nabi 
Saw. Dalam salah satu haditsnya Rasulullah Saw. bersabda, "Sesungguhnya aku hanya diutus untuk menyempurnakan akhlak yang mulia". (HR. Ahmad). Sedangkan dalam al-Quran hanya ditemukan bentuk tunggal dari akhlaq yaitu khuluq. Allah menegaskan, "Dan sesungguhnya kamu benar-benar berbudi pekerti yang agung." (QS. al-Qalam (68): 4). Khuluq adalah ibarat dari kelakuan manusia yang membedakan baik dan buruk, lalu disenangi dan dipilih yang baik untuk dipraktikkan dalam perbuatan, sedang yang buruk dibenci dan dihilangkan (Ainain, 1985: 186).

Kata yang setara maknanya dengan akhlak adalah moral dan etika. Kata-kata ini sering disejajarkan dengan budi pekerti, tata susila, tata krama atau sopan santun (Faisal Ismail, 1998: 178). Satu kata lagi yang sekarang menjadi lebih polpuler adalah karakter yang juga memiliki makna yang hampir sama dengan akhlak, moral, dan etika. Pada dasarnya secara konseptual kata etika dan moral mempunyai pengertian serupa, yakni sama-sama membicarakan perbuatan dan perilaku manusia ditinjau dari sudut pandang nilai baik dan buruk. Akan tetapi dalam aplikasinya etika lebih bersifat teoritis filosofis sebagai acuan untuk mengkaji sistem nilai, sedang moral bersifat praktis sebagai tolok ukur untuk menilai perbuatan yang dilakukan oleh seseorang (Muka Sa'id, 1980: 23-24). Etika memandang perilaku secara universal, sedang moral secara memandangnya secara lokal.

Adapun karakter lebih ditekankan pada aplikasi nilai-nilai positif dalam kehidupan sehari-hari. Jadi, karakter lebih mengarah kepada sikap dan perilaku manusia. Konsep pendidikan karakter mulai dikenalkan sejak tahun 1900-an. Thomas Lickona (dalam Ary Ginanjar Agustian, 2005) dianggap sebagai pengusungnya, terutama ketika ia menulis buku yang berjudul The Return of Character Education. Melalui buku ini, ia menyadarkan dunia Barat akan pentingnya pendidikan karakter. Pendidikan karakter, menurut Ryan dan Bohlin, mengandung tiga unsur pokok, yaitu mengetahui kebaikan (knowing the good), mencintai kebaikan (loving the good), dan melakukan kebaikan (doing the good). Pendidikan Karakter tidak sekedar mengajarkan mana yang benar dan mana yang salah kepada anak, tetapi lebih dari itu pendidikan karakter menanamkan kebiasaan (habituation) tentang yang baik sehingga siswa paham, mampu merasakan, dan mau melakukan yang baik. Jadi, pendidikan karakter membawa misi yang sama dengan Pendidikan Akhlak atau Pendidikan Moral.

Sumber untuk menentukan akhlak dalam Islam, apakah termasuk akhlak yang mulia atau akhlak yang tercela, sebagaimana keseluruhan ajaran Islam lainnya adalah al-Quran dan Sunnah Nabi Muhammad 
Saw. Baik dan buruk dalam akhlak Islam ukurannya adalah baik dan buruk menurut kedua sumber itu, bukan baik dan buruk menurut ukuran manusia. Sebab jika ukurannya adalah manusia, maka baik dan buruk itu bisa berbeda-beda. Seseorang mengatakan bahwa sesuatu itu baik, tetapi orang lain belum tentu menganggapnya baik. Begitu juga sebaliknya, seseorang menyebut sesuatu itu buruk, padahal yang lain bisa saja menyebutnya baik.

Kedua sumber ajaran Islam yang pokok itu (al-Quran dan Sunnah) diakui oleh semua umat Islam sebagai dalil naqli yang tinggal mentransfernya dari Allah Swt. dan Rasulullah Saw. Keduanya hingga sekarang masih terjaga keautentikannya, kecuali Sunnah Nabi yang memang dalam perkembangannya banyak ditemukan hadits-hadits yang tidak benar (dla'if/palsu). Melalui kedua sumber inilah kita dapat memahami bahwa sifat-sifat sabar, tawakkal, syukur, pemaaf, dan pemurah termasuk sifat-sifat yang baik dan mulia. Sebaliknya, kita juga memahami bahwa sifat-sifat syirik, kufur, nifaq, ujub,takabur, dan hasad merupakan sifat-sifat tercela. Jika kedua sumber itu tidak menegaskan mengenai nilai dari sifat-sifat tersebut, akal manusia mungkin akan memberikan nilai yang berbeda-beda.

Namun demikian, Islam tidak menafikan adanya standar lain selain al-Quran dan Sunnah untuk menentukan baik dan buruknya akhlak manusia. Standar lain yang dapat dijadikan untuk menentukan baik dan buruk adalah akal dan nurani manusia serta pandangan umum masyarakat. Manusia dengan hati nuraninya dapat juga menentukan ukuran baik dan buruk, sebab Allah memberikan potensi dasar kepada manusia berupa tauhid (QS. al-A'raf (7): 172 dan QS. al-Rum (30): 30). Dengan fitrah tauhid inilah manusia akan mencintai kesucian dan cenderung kepada kebenaran. Hati nuraninya selalu mendambakan dan merindukan kebenaran, ingin mengikuti ajaran-ajaran Allah dan Rasul-Nya, karena kebenaran itu tidak akan dicapai kecuali dengan Allah sebagai sumber kebenaran mutlak. Namun demikian, harus diakui bahwa fitrah manusia tidak selalu dapat berfungsi dengan baik. Pendidikan dan pengalaman manusia dapat memengaruhi eksistensi fitrah manusia itu. Dengan pengaruh tersebut tidak sedikit fitrah manusia menjadi kotor dan tertutup sehingga tidak lagi dapat menentukan baik dan buruk dengan benar. Karena itulah ukuran baik dan buruk tidak dapat diserahkan kepada hati nurani belaka, tetapi harus dikembalikan kepada wahyu yang terjamin kebenarannya (Yunahar Ilyas, 2004: 4).

Akal pikiran manusia juga sama kedudukannya seperti hati nurani di atas. Kebaikan atau keburukan yang diperoleh akal bersifat 
subjektif dan relatif. Karena itu, akal manusia tidak dapat menjamin ukuran baik dan buruknya akhlak manusia. Hal yang sama juga terjadi pada pandangan umum masyarakat. Yang terakhir ini juga bersifat relatif, bahkan nilainya paling rendah dibandingkan kedua standar sebelumnya. Hanya masyarakat yang memiliki kebiasaan (tradisi) yang baik yang dapat memberikan ukuran yang lebih terjamin.

\section{Ruang Lingkup Akhlak Mulia dalam Islam}

Secara umum akhlak Islam dibagi menjadi dua, yaitu akhlak mulia (al-akhlaq al-mahmudah/al-karimah) dan akhlak tercela (al-akhlaq al-madzmumah/al-qabihah). Akhlak mulia harus diterapkan dalam kehidupan sehari-hari, sedang akhlak tercela harus dijauhi jangan sampai dipraktikkan dalam kehidupan sehari-hari.

Dilihat dari ruang lingkupnya, akhlak Islam dibagi menjadi dua bagian, yaitu akhlak terhadap Khaliq (Allah Swt.) dan akhlak terhadap makhluq (ciptaan Allah). Akhlak terhadap makhluk masih dirinci lagi menjadi beberapa macam, seperti akhlak terhadap sesama manusia, akhlak terhadap makhluk hidup selain manusia (seperti tumbuhan dan binatang), serta akhlak terhadap benda mati.

Orang Islam yang memiliki aqidah yang benar dan kuat, berkewajiban untuk berakhlak baik kepada Allah Swt. dengan cara menjaga kemauan dengan meluruskan ubudiyah dengan dasar tauhid (QS. al-Ikhlash (112): 1-4; QS. al-Dzariyat (51): 56), menaati perintah Allah atau bertakwa (QS. Ali 'Imran (3): 132), ikhlas dalam semua amal (QS. al-Bayyinah (98): 5), cinta kepada Allah (QS. al-Baqarah (2): 165), takut kepada Allah (QS. Fathir (35): 28), berdoa dan penuh harapan (raja') kepada Allah Swt. (QS. al-Zumar (39): 53), berdzikir (QS. al-Ra'd (13): 28), bertawakal setelah memiliki kemauan dan ketetapan hati (QS. Ali 'Imran (3): 159, QS. Hud (11): 123), bersyukur (QS. al-Baqarah (2): 152 dan QS. Ibrahim (14): 7), bertaubat serta istighfar bila berbuat kesalahan (QS. al-Nur (24): 31 dan QS. al-Tahrim (66): 8), rido atas semua ketetapan Allah (QS. al-Bayyinah (98): 8), dan berbaik sangka pada setiap ketentuan Allah (QS. Ali 'Imran (3): 154).

Akhlak terhadap sesama manusia harus dimulai dari akhlak terhadap Rasulullah Saw., sebab Rasullah yang paling berhak dicintai, baru dirinya sendiri. Di antara bentuk akhlak kepada Rasulullah adalah cinta kepada Rasul dan memuliakannya (QS. al-Taubah (9): 24), taat kepadanya (QS. al-Nisa' (4): 59), serta mengucapkan shalawat dan salam kepadanya (QS. al-Ahzab (33): 56). Namun demikian akhlak terhadap Rasulullah Saw. ini juga sangat terkait dengan Akhlak terhadap Allah Swt., sebab apa pun yang bersumber dari Allah 
(al-Quran) dan Rasulullah (sunnah) harus dijadikan dasar dalam bersikap dan berpreilaku dalam kehidupan sehari-hari.

Selanjutnya seorang Muslim harus berakhlak mulia terhadap sesama manusia, baik terhadap dirinya sendiri, terhadap keluarganya, dan terhadap orang lain di tengah-tengah masyarakat. Ketiga akhlak ini sangat penting artinya bagi kita, karena sikap dan perilaku terkait dengan hubungan antar sesama ini yang tampak di permukaan yang sering dinilai oleh masyarakat pada umumnya. Ketiga bentuk akhlak ini akan dibicarakan secara rinci pada uraian selanjutnya.

Yang tidak boleh ditinggalkan dalam pembinaan akhak mulia adalah akhlak terhadap lingkungan. Lingkungan yang dimaksud di sini adalah segala sesuatu yang berada di sekitar manusia, yakni binatang, tumbuhan, dan benda mati. Akhlak yang dikembangkan adalah cerminan dari tugas kekhalifahan di bumi, yakni untuk menjaga agar setiap proses pertumbuhan alam terus berjalan sesuai dengan fungsi ciptaan-Nya. Dalam al-Quran Surat al-An'am (6): 38 dijelaskan bahwa binatang melata dan burung-burung adalah seperti manusia yang menurut Qurtubi tidak boleh dianiaya (Shihab, 1996: 270). Baik di masa perang apalagi ketika damai akhlak Islam menganjurkan agar tidak ada pengrusakan binatang dan tumbuhan kecuali terpaksa, tetapi sesuai dengan sunnatullah dari tujuan dan fungsi penciptaan (QS. al-Hasyr (59): 5).

\section{Pembinaan Akhlak Mulia dalam Ber-hablun Minannas}

Hablun minannas adalah berhubungan antar sesama manusia. Sebagai umat beragama, setiap orang harus menjalin hubungan baik antar sesamanya setelah menjalin hubungan baik dengan Tuhannya. Dalam kenyataan sering kita saksikan dua hubungan ini tidak padu. Terkadang ada seseorang yang dapat menjalin hubungan baik dengan Tuhannya, tetapi ia bermasalah dalam menjalin hubungan dengan sesamanya. Atau sebaliknya, ada orang yang dapat menjalin hubungan secara baik dengan sesamanya, tetapi ia mengabaikan hubungannya dengan Tuhannya. Tentu saja kedua contoh ini tidak benar. Yang seharusnya dilakukan adalah bagaimana ia dapat menjalin dua bentuk hubungan itu dengan baik, sehingga terjadi keharmonisan dalam dirinya.

Pada prinsipnya ada tiga bahasan pokok terkait dengan pembinaan akhlak mulia dalam berhubungan antar sesama manusia ini. Bahasan pertama terkait dengan akhlak manusia terhadap diri sendiri. Akhlak ini bertujuan untuk membekali manusia dalam bereksistensi diri di hadapan orang lain dan terutama di hadapan Allah Swt. Bahasan 
kedua terkait dengan akhlak manusia dalam kehidupan keluarganya. Akhlak ini bertujuan membekali manusia dalam hidup di tengah-tengah keluarga dalam posisinya masing-masing. Dan bahasan ketiga terkait dengan akhlak manusia dalam kehidupan bermasyarakat. Akhlak ini membekali manusia bagaiman bisa berkiprah di tengah-tengah masyarakatnya dengan baik dan tetap berpegang pada nilai-nilai akhlak yang sudah digariskan oleh ajaran Islam.

\section{Akhlak terhadap diri sendiri}

Untuk membekali kaum Muslim dengan akhlak mulia terutama terhadap dirinya, di bawah akan diuraikan beberapa bentuk akhlak mulia terhadap diri sendiri dalam berbagai aspeknya. Di antara bentuk akhlak mulia ini adalah memelihara kesucian diri baik lahir maupun batin. Orang yang dapat memelihara dirinya dengan baik akan selalu berupaya untuk berpenampilan sebaik-baiknya di hadapan Allah, khususnya, dan di hadapan manusia pada umumnya dengan memperhatikan bagaimana tingkah lakunya, bagaimana penampilan fisiknya, dan bagaimana pakaian yang dipakainya. Pemeliharaan kesucian diri seseorang tidak hanya terbatas pada hal yang bersifat fisik (lahir) tetapi juga pemeliharaan yang bersifat nonfisik (batin). Yang pertama harus diperhatikan dalam hal pemeliharaan nonfisik adalah membekali akal dengan berbagai ilmu yang mendukungnya untuk dapat melakukan berbagai aktivitas dalam hidup dan kehidupan sehari-hari. Berbagai upaya yang mendukung ke arah pembekalan akal harus ditempuh, misalnya melalui pendidikan yang dimulai dari lingkungan rumah tangganya kemudian melalui pendidikan formal hingga mendapatkan pengetahuan yang memadai untuk bekal hidupnya (QS. al-Zumar (39): 9). Setelah penampilan fisiknya baik dan akalnya sudah dibekali dengan berbagai ilmu pengetahuan, maka yang berikutnya harus diperhatikan adalah bagaimana menghiasi jiwanya dengan berbagai tingkah laku yang mencerminkan akhlak mulia. Di sinilah seseorang dituntut untuk berakhlak mulia di hadapan Allah dan Rasulullah, di hadapan orang tuanya, di tengah-tengah masyarakatnya, bahkan untuk dirinya sendiri.

Sabar juga ujud dari akhlak mulia terhadap diri sendiri. Sabar berarti menahan diri dari segala sesuatu yang tidak disukai karena mengharap rido dari Allah Swt. (al-Qardlawi, 1989: 8). Imam al-Ghazali mengemukakan, sabar adalah suatu kondisi mental dalam mengendalikan nafsu yang tumbuhnya atas dorongan ajaran agama. Dengan kata lain, sabar ialah tetap tegaknya dorongan agama berhadapan dengan dorongan hawa nafsu (al-Ghazali, 1995: 236). 
Macam atau tingkatan sabar menurut Nabi Muhammad Saw., seperti dalam hadits yang diriwayatkan oleh Ibnu Abi ad-Dunya, ada tiga tingkatan, yaitu: 1) sabar dalam menghadapi musibah, 2) sabar dalam mematuhi perintah Allah, dan 3) sabar dalam menahan diri untuk tidak melakukan maksiat. Yang pertama merupakan tingkatan sabar yang terendah dan yang ketiga merupakan tingkatan sabar yang tertinggi.

Bentuk lain dari akhlak mulia terhadap diri sendiri adalah wara' dan zuhud. Menurut al-Jarjani (1988: 252) wara' berarti menjauhkan hal-hal yang syubhat (hal-hal yang belum jelas halal dan haramnya) karena khawatir akan jatuh ke dalam hal-hal yang diharamkan. Wara' termasuk akhlak yang sangat terpuji yang tidak semua orang mampu memilikinya. Hanya orang-orang tertentu yang dapat melakukan wara' ini. Dalam kehidupan modern yang serba gemerlapan seperti sekarang ini, gaya hedonisme (sangat berorientasi keduniaan) menjadi kecenderungan kebanyakan orang. Manusia berlomba-lomba dengan kekayaan dan kehebatannya, meskipun semuanya diperoleh dengan cara yang tidak halal dan tidak wajar. Tentu saja hal ini sangat bertentangan dengan sifat wara' yang menuntut seseorang harus hati-hati dalam mencari harta dan membelanjakannya. Sedangkan zuhud berarti membatasi ambisi-ambisi duniawi, syukur terhadap setiap anugerah, dan menghindari apa yang telah diharamkan oleh Allah Swt. (Sultani, 2004: 213). Dengan demikian, zuhud tidak berarti membuang harta benda dan menolak apa yang dibolehkan, tetapi zuhud berarti bahwa kita tidak boleh beranggapan bahwa apa saja yang kita miliki, harta atau kekuasaan, adalah lebih aman dari pada apa yang ada di sisi Allah Swt. Menurut al-Ghazali (1995: 226), esensi zuhud adalah menjauhkan diri dari kehidupan dunia dan memalingkan diri daripadanya dengan penuh kepatuhan kepada Allah Swt. Sikap zuhud seperti ini akan muncul jika didasari dengan ilmu dan cahaya yang memancar dari kalbu seseorang serta kelapangan dada dalam memandang dunia. Orang yang zuhud adalah orang yang tidak menyintai dunia secara berlebihan. Orang yang zuhud juga bukan orang yang meninggalkan dunia secara total dan ia menyintai dunia hanya sekedarnya, sebab ada yang lebih berhak untuk dicintai, yakni Allah Swt. Ia menjadikan dunia sebagai sarana untuk mendapatkan cinta dan rido dari Allah Swt.

Bentuk akhlak mulia yang juga penting adalah syaja'ah (berani). Dalam Kamus Besar Bahasa Indonesia (2001: 138) berani diartikan mempunyai hati yang mantap dan percaya diri yang besar dalam menghadapi bahaya, kesulitan, dsb. Dengan demikian, berani di sini adalah berani yang bernilai positif, bukan berani yang bernilai negatif, 
seperti berani berbuat kesalahan atau berani yang tujuannya hanya untuk pelampiasan nafsu belaka. Lawan dari sifat syaja'ah adalah jubun (pengecut atau penakut). Orang yang berani (pemberani) adalah orang yang berani membela kebenaran dengan resiko apa pun dan takut untuk berbuat yang tidak benar. Sebaliknya orang yang takut (penakut) adalah orang takut membela kebenaran. Dari hadits Nabi Saw. (HR. al-Bukhari dan Muslim) terlihat bahwa ukuran berani atau tidaknya seseorang tidak bisa dilihat dari segi fisiknya, tetapi dari segi jiwanya. Orang yang memiliki fisik yang kekar, seperti binaragawan, belum tentu dapat dimasukkan ke dalam sifat ini. Banyak orang fisiknya kuat tidak memiliki sifat syaja'ah ini. Sebab keberanian tidak ditentukan dari situ, tetapi dari kekuatan jiwanya yang selalu menggerakkan untuk berbuat baik, meskipun harus menghadapi kekuatan-kekuatan di luar. Di antara wujud sikap berani di antaranya adalah: 1) berani dalam menghadapi musuh dalam peperangan di jalan Allah (jihad fi sabilillah); 2) berani untuk menegakkan kebenaran, meskipun berbahaya; dan 3) berani untuk mengendalikan hawa nafsu. Untuk menumbuhkan keberanian pada seorang Muslim, menurut Raid Abdul Hadi (dalam Yunahar Ilyas, 2004: 118-121), ada tujuh hal yang dapat dilakukan, yaitu 1) adanya rasa takut kepada Allah Swt.; 2) lebih mencintai akhirat daripada dunia; 3 ) tidak takut mati; 4) tidak ragu-ragu; 5) tidak menomorsatukan kekuatan materi; 6) tawakkal dan yakin akan pertolongan Allah Swt.; dan 7) karena hasil pendidikan.

Itulah beberapa bentuk akhlak mulia manusia terhadap dirinya sendiri. Masih banyak bentuk akhlak mulia yang lain yang harus dilakukan oleh seseorang yang tidak dapat diuraikan satu persatu. Di antara bentuk-bentuknya yang lain adalah 1) istiqamah (konsisten), 2) amanah (terpercaya), 3) shiddiq (jujur), 4) menepati janji, 5) adil, 6) tawadlu' (rendah hati), 7) malu (berbuat jelek), 8) pemaaf, 9) berhati lembut, 10) setia, 11) kerja keras, 12) tekun, 13) ulet, 14) teliti, 15) disiplin, 16) berinisiatif, 17) percara diri, dan 18) berpikir positif. Sikap dan perilaku mulia seperti ini harus diupayakan secara bertahap dan berkesinambungan, sehingga terwuud pribadi yang berkarakter yang dapat menampilkan dirinya dengan kepribadian yang utuh dan mulia di tengah-tengah masyarakat.

\section{Akhlak dalam lingkungan keluarga}

Di samping harus berakhlak mulia terhadap dirinya, setiap Muslim harus berakhlak mulia dalam lingkungan keluarganya. Pembinaan akhlak mulia dalam lingkungan keluarga meliputi hubungan seseorang dengan orang tuanya, termasuk dengan 
guru-gurunya, hubungannya dengan orang yang lebih tua atau dengan yang lebih muda, hubungan dengan teman sebayanya, dengan lawan jenisnya, dan dengan suami atau isterinya serta dengan anak-anaknya.

Menjalin hubungan dengan orang tua atau guru memiliki kedudukan yang sangat istimewa dalam pembinaan akhlak mulia di lingkungan keluarga. Guru juga bisa dikategorikan sebagai orang tua kita. Orang tua nomor satu adalah orang tua yang melahirkan kita dan orang tua kedua adalah orang tua yang memberikan kepandaian kepada kita. Islam menetapkan bahwa berbuat baik kepada kedua orang tua (birr al-walidain) adalah wajib dan merupakan amalan utama (QS. al-Isra' (17): 23-24 dan HR. al-Bukhari dan Muslim). Berakhlak mulia dengan kepada orang tua bisa dilakukan di antaranya dengan 1) mengikuti keinginan dan saran kedua orang tua dalam berbagai aspek kehidupan; 2) menghormati dan memuliakan kedua orang tua dengan penuh rasa terima kasih dan kasih sayang atas jasa-jasa keduanya; 3) membantu kedua orang tua secara fisik dan material; 4) mendoakan kedua orang tua agar selalu mendapatkan ampunan, rahmat, dan karunia dari Allah (QS. al-Isra' (17): 24); dan 5) jika kedua orang tua telah meninggal, maka yang harus dilakukan adalah mengurus jenazahnya dengan sebaik-baiknya, melunasi hutang-hutangnya, melaksanakan wasiatnya, meneruskan silaturrahim yang dibina orang tua di waktu hidupnya, memuliakan sahabat-sahabatnya, dan mendoakannya. Jadi, kita wajib berbuat baik kepada kedua orang tua kita (birr al-walidain) dan jangan sekali-kali kita durhaka kepada keduanya. Hal yang hampir sama juga harus kita lakukan terhadap guru-guru kita.

Untuk menjalin hubungan dengan orang-orang yang lebih tua, yang kita lakukan tidak jauh berbeda dengan apa yang kita lakukan terhadap kedua orang tua dan guru, selama orang yang lebih tua itu patut untuk diperlakukan seperti itu. Jika mereka adalah saudara kita, maka kita harus memberikan penghormatan yang sebaik-baiknya, apalagi jika mereka adalah saudara dari bapak atau ibu kita. Ketika kedua orang tua kita sudah meninggal, mereka dapat mengganti kedudukan kedua orang tua kita. Jika mereka itu bukan saudara kita, maka kita tetap harus menghormatinya, selama mereka layak untuk dihormati. Sedang dengan orang-orang yang lebih muda, jika mereka saudara kita, kita harus memberikan kasih sayang kita yang sepenuhnya dengan ikut merawat mereka, membimbing, mendidik, dan membantu mereka jika mereka membutuhkan bantuan kita. Jika mereka bukan saudara kita, kita tetap harus menyayangi mereka dengan menunjukkan kasih sayang kita kepada mereka, jangan sekali-kali kita menyakiti 
mereka dan melakukan sesuatu yang mengganggu pertumbuhan dan perkembangan mereka, baik dari segi fisik maupun mental atau kejiwaan mereka.

Dalam berhubungan dengan teman-teman sebaya kita harus dapat bergaul dengan sebaik-baiknya. Mereka ini adalah orang-orang yang sehari-harinya bergaul dengan kita dan menemani kita baik di kala suka maupun di kala duka. Yang dapat kita lakukan misalnya adalah saling memberi salam setiap bertemu dan berpisah dengan mereka dan dilanjutkan saling berjabat tangan, kecuali jika mereka itu lawan jenis kita, saling menyambung tali silaturrahim dengan mereka, saling memahami kelebihan dan kekurangan serta kekuatan dan kelemahan masing-masing, sehingga segala macam bentuk kesalahfahaman dapat dihindari, saling tolong-menolong, bersikap rendah hati dan tidak boleh bersikap sombong kepada mereka, saling mengasihi dengan mereka, memberi perhatian terhadap keadaan mereka, selalu membantu keperluan mereka, apalagi jika mereka meminta kita untuk membantu, ikut menjaga mereka dari gangguan orang lain, saling memberi nasihat dengan kebaikan dan kesabaran, mendamaikan mereka bila berselisih, dan saling mendoakan dengan kebaikan.

Terkait dengan pembinaan akhlak mulia terhadap orang-orang yang menjadi lawan jenis kita, Islam memberikan aturan yang khusus yang harus kita pegangi dalam rangka bergaul dengan mereka. Di antara ketentuan itu adalah 1) Tidak melakukan khalwat, yaitu berdua-duaan antara seorang laki-laki dan seorang perempuan yang tidak mempunyai hubungan suami isteri dan tidak pula mahram tanpa ada orang ketiga; 2) tidak melakukan jabat tangan, kecuali terhadap suami atau isterinya, atau terhadap mahramnya; 3) mengurangi pandangan mata, kecuali yang memang benar-benar perlu; 4) tidak boleh menampakkan aurat di hadapan lawan jenisnya dan juga tidak boleh saling melihat aurat; dan 5) tidak melakukan hal-hal yang menjurus kepada perzinaan, seperti bergandengan tangan, berciuman, berpelukan, dan yang sejenisnya. Hubungan antarlawan jenis ini menjadi berubah ketentuannya ketika keduanya sudah menjalin hubungan pernikahan (suami-isteri). Hubungan antara keduanya yang semula haram menjadi halal, bahkan bisa bernilai ibadah. Keduanya menjadi satu kesatuan dalam keluarga yang bersama-sama bertanggung jawab membawa keutuhan keluarga, termasuk anak-anak mereka. Kewajiban keduanya selaku orang tua terhadap anaknya, di samping memberikan kasih sayang kepadanya, juga harus melindunginya, merawatnya, dan mendidiknya hingga menjadi manusia dewasa yang utuh kepribadiannya dan siap membina rumah tangga. 


\section{Akhlak di tengah-tengah masyarakat}

Yang dimaksud dengan pembinaan akhlak mulia di tengah masyarakat di sini adalah menjalin hubungan baik yang tidak terfokus hanya pada pergaulan antar manusia secara individual, tetapi lebih terfokus pada perilaku kita dalam kondisi yang berbeda-beda, seperti bagaimana bersikap sopan ketika kita sedang bepergian, ketika dalam berkendaraan, ketika bertamu dan menerima tamu, ketika bertetangga, ketika makan dan minum, ketika berpakaian, serta ketika berhias.

Salah satu sikap penting yang harus ditanamkan dalam diri setiap Muslim adalah sikap menghormati dan menghargai orang lain. Orang lain bisa diartikan sebagai orang yang selain dirinya, baik keluarganya maupun di luar keluarganya. Orang lain juga bisa diartikan orang yang bukan termasuk dalam keluarganya, bisa temannya, tetangganya, atau orang yang selain keduanya. Dalam konteks beragama, orang lain bisa juga diartikan orang yang tidak seiman dengan kita, atau orang yang tidak memeluk agama Islam.

Terhadap orang lain yang seiman (sesama Muslim), kita harus membina tali silaturrahim dan memenuhi hak-haknya seperti yang dijelaskan dalam hadits Nabi Saw. Dalam salah satu haditsnya, Nabi Saw. menyebutkan adanya lima hak seorang Muslim terhadap Muslim lainnya, yaitu 1) apabila bertemu, berilah salam kepadanya, 2) mengunjunginya, apabila ia (Muslim lain) sedang sakit, 3) mengantarkan jenazahnya, apabila ia meninggal dunia, 4) memenuhi undangannya, apabila ia mengundang, dan 5) mendoakannya, apabila ia bersin (HR. al-Bukhari dan Muslim). Terhadap suami atau isteri dan anak-anak kita, kita harus saling menjalin hubungan kasih sayang demi ketenteraman keluarga kita. Terhadap tetangga, kita harus selalu berbuat baik. Jangan sampai kita menyakiti tetangga kita (HR. al-Bukhari). Terhadap tamu, kita harus memuliakan dan menghormatinya. Nabi memerintahkan kepada kita agar selalu memuliakan tamu (HR. al-Bukhari dan Muslim), dan segera menyambut kedatangannya serta mengantarkan kepergiannya. Terhadap orang alim (ulama) dan cendekiawan, kita harus menghormati keluasan ilmunya dan berusaha untuk selalu bergaul dan mendekatinya. Terhadap para pemimpin, kita harus menaati mereka selama tidak menyimpang dari aturan agama. Menaati pemimpin yang benar berarti menaati Allah Swt. (HR. al-Bukhari dan Muslim). Jika mampu kita harus memberikan saran dan nasehat yang baik kepada mereka demi kemajuan yang dipimpinnya.

Adapun terhadap orang-orang yang lemah, seperti fakir miskin dan anak yatim, kita harus berbuat baik dengan menyantuni mereka, 
memberikan makanan dan pakaian kepada mereka, dan melindungi mereka dari gangguan yang membahayakan mereka. Jangan sekali-kali kita berlaku sewenang-wenang kepada anak yatim dan menghardik orang yang minta-minta (QS. al-Dluha (93): 9-10).

Terhadap mereka yang tidak seiman, Islam memberikan beberapa batasan khusus seperti tidak boleh mengadakan hubungan perkawinan dengan mereka, tidak memberi salam kepada mereka, dan tidak meniru cara-cara mereka. Ukuran hubungan dengan mereka yang tidak seiman adalah selama tidak masuk pada ranah aqidah dan syariah. Di luar kedua hal ini, Islam tidak melarang kita berhubungan dengan mereka. Terhadap mereka yang mengancam agama kita, kita harus berbuat tegas (QS. al-Mumtahanah (60): 9). Dan jika mereka berkhianat, kita pun harus memerangi mereka (QS. al-Anfal (8): 56-57).

Itulah beberapa cara dalam rangka membina akhlak mulia di tengah-tengah masyarakat secara umum. Secara khusus bentuk-bentuk akhlak mulia di masyarakat ini dapat dilakukan dengan cara 1) menyayangi yang lemah; 2) menyayangi anak yatim; 3) suka menolong; 4) bersijap pemurah dan dermawan; 5) melakukan amar ma'ruf nahi munkar (menyuruh kepada yang ma'ruf dan mencegah dari yang munkar); 6) menaati ulama dan ulil amri; 7) bersikap toleran; dan 8) sopan dalam bepergian, dalam berkendaraan, dalam bertamu dan menerima tamu, dalam bertetangga, dalam makan dan minum, dan dalam berpakaian.

\section{Penutup}

Itulah beberapa bentuk akhlak mulia dan tatacaranya yang dapat dilakukan dalam rangka pembinaan akhlak antar sesama manusia. Tentu saja uraian ini tidak mencakup keseluruhan bagian-bagian dari keseluruhan masalahnya. Untuk lebih lanjut silahkan diikuti uraian-uraian yang lebih luas di literatur lain.

Yang terpenting ditegaskan di sini adalah pembinaan akhlak mulia bukanlah sesuatu yang mudah, tetapi bukan sesuatu yang tidak mungkin. Artinya sesulit apapun pembinaan akhlak mulia ini bisa dilakukan, ketika ada komitmen (niat) yang kuat untuk melakukannya dan didukung oleh usaha keras serta selalu bertawakkal dan mengharap rido dari Allah Swt. bukan tidak mungkin akhlak mulia ini akan menjadi bagian yang tidak terpisahkan dari sikap dan perilaku sehari-hari. 


\section{Daftar Pustaka}

Ainain, Ali Khalil Abu. 1985. Falsafah al-Tarbiyah fi al-Quran al-Karim. T.tp.: Dar al-Fikr al-'Arabiy.

Al-Ghazali, Imam. 1995. Teosofia Al-Qur'an. Terj. oleh M. Luqman Hakiem dan Hosen Arjaz Jamad. Surabaya: Risalah Gusti.

Al-Hadits al-Nabawiy.

Al-Jarjani, 'Ali Ibn Muhammad. 1988. Kitab al-Ta'rifat. Beirut: Dar al-Kutub al-'Ilmiyyah.

Al-Qura'an al-Karim.

Ary Ginanjar Agustian. 2005. Emotional Spiritual Quotient. Jakarta: Penerbit Arga.

Faisal Ismail. 1988. Paradigma Kebudayaan Islam. Yogyakarta: Titihan Ilahi Press.

Muka Sa'id. 1986. Etika Masyarakat Indonesia. Jakarta: Pradnya Paramita.

Shihab, M. Quraish. 1996. Wawasan Al-Qur'an. Bandung: Mizan.

Sultani, Gulam Reza. 2004. Hati yang Bersih Kunci Ketenangan Jiwa. Terj. oleh Abdullah Ali. Jakarta: Pustaka Zahra.

Tim Redaksi Kamus Besar Bahasa Indonesia. 2001. Kamus Besar Bahasa Indonesia. Jakarta: Balai Pustaka. Cet. Pertama Edisi III.

Yunahar Ilyas. 2004. Kuliah Akhlaq. Yogyakarta: LPPI UMY. Cet. IV.

\section{Biodata Penulis:}

Dr. Marzuki, M.Ag., dilahirkan di Banyuwangi, 21 April 1966. Menyelesaikan studi S-1 di IAIN Sunan Kalijaga Yogyakarta Fakultas Tarbiyah (1990). Menyelesaikan studi S-2 di PPS Jurusan Pengkajian Islam IAIN (sek. UIN) Syarif Hidayatullah Jakarta (1997). Studi S-3 diselesaikan di lembaga yang sama tahun 2007. Sekarang menjadi dosen tetap di Jurusan PKn dan Hukum Fakultas Ilmu Sosial dan Ekonomi Universitas Negeri Yogyakarta dengan mata kuliah Pendidikan Agama Islam dan Hukum Islam. 